\title{
The L-type voltage-gated calcium channel Cav1.2 mediates fear extinction and modulates synaptic tone in the lateral amygdala
}

\author{
Stephanie J. Temme ${ }^{1}$ and Geoffrey G. Murphy ${ }^{1,2,3}$ \\ ${ }^{1}$ Neuroscience Graduate Program; ${ }^{2}$ Molecular and Behavioral Neuroscience Institute; ${ }^{3}$ Department of Molecular and Integrative \\ Physiology, University of Michigan, Ann Arbor, Michigan 48109-2200, USA
}

\begin{abstract}
L-type voltage-gated calcium channels (LVGCCs) have been implicated in both the formation and the reduction of fear through Pavlovian fear conditioning and extinction. Despite the implication of LVGCCs in fear learning and extinction, studies of the individual LVGCC subtypes, Cav1.2 and Cav1.3, using transgenic mice have failed to find a role of either subtype in fear extinction. This discontinuity between the pharmacological studies of LVGCCs and the studies investigating individual subtype contributions could be due to the limited neuronal deletion pattern of the Cavl.2 conditional knockout mice previously studied to excitatory neurons in the forebrain. To investigate the effects of deletion of Cav1.2 in all neuronal populations, we generated $C_{v} 1.2$ conditional knockout mice using the synapsinl promoter to drive Cre recombinase expression. Pan-neuronal deletion of Cav1.2 did not alter basal anxiety or fear learning. However, pan-neuronal deletion of Cav1.2 resulted in a significant deficit in extinction of contextual fear, implicating LVGCCs, specifically Cav1.2, in extinction learning. Further exploration on the effects of deletion of Cav1.2 on inhibitory and excitatory input onto the principle neurons of the lateral amygdala revealed a significant shift in inhibitory/excitatory balance. Together these data illustrate an important role of Cav1.2 in fear extinction and the synaptic regulation of activity within the amygdala.
\end{abstract}

[Supplemental material is available for this article.]

Throughout life, we establish adaptive behaviors through the formation of fear-related memories of aversive stimuli. While these associations serve to protect us from harm, pathological fear, such as fear to a nonthreatening stimulus, can interfere with an individual's quality of life. Pathological fears are often associated with psychiatric disease, including acute stress disorder and posttraumatic stress disorder (American Psychiatric Association 2013). Treatments for such disorders are often only moderately effective, and typically involve attempts to reduce or eliminate the learned fear response through techniques such as exposure therapy (Hofmann 2007; Gordon et al. 2013; Furini et al. 2014). The development of more effective behavioral and pharmacological treatments of trauma and anxiety-related disorders will likely require a deeper understanding of the neurobiological substrates that underlie the acquisition, consolidation, and modification of fear memories.

In the laboratory, the formation and modification of learned fear is often studied using Pavlovian fear conditioning and extinction (Maren 2001; Garakani et al. 2006; Furini et al. 2014). During Pavlovian fear conditioning, a neutral conditioned stimulus (CS), such as a tone or context, is paired with an aversive unconditioned stimulus (US), such as a footshock.

Following even a single CS-US pairing, the conditioned stimulus alone is sufficient to trigger a fear response (Kalish 1954; Maren and Fanselow 1996). Fear of the CS can then be reduced through fear extinction. During fear extinction the CS is presented repeatedly in the absence of the US (Kalish 1954; Myers and Davis 2002). Studies attempting to uncover the neurobiology underlying Pavlovian fear conditioning and fear extinction have identified the

\section{Corresponding author: murphyg@umich.edu}

Article is online at http://www.learnmem.org/cgi/doi/10.1101//m.045773.117. amygdala as the key brain structure involved in the processing of fearful memories (Maren and Fanselow 1996; Barad et al. 2006; Pape and Pare 2010). Regulation of basal activity in the amygdala and plasticity within amygdala-associated circuits is thought to play a key role in both the establishment and extinction of conditioned fear (Maren 1996; Sah et al. 2008; Pape and Pare 2010). Activity within the amygdala is thought to be regulated by excitatory and inhibitory inputs from regions of the prefrontal cortex and the hippocampus, as well as structures associated with the processing of the conditioned and unconditioned stimuli (Tovote et al. 2015). Additionally, fear extinction is thought to induce remodeling of local inhibitory neurons within the amygdala that mediate activity (Heldt and Ressler 2007).

It is well appreciated that changes in intracellular calcium can influence basal activity as well as neuronal plasticity (Blair et al. 2001; Clapham 2007). One major source of intracellular calcium is the influx of calcium through voltage-gated calcium channels. Blockade of L-type voltage-gated calcium channels (LVGCCs) using nonsubtype specific antagonists has revealed a potential role of LVGCCs in plasticity within the amygdala (Weisskopf et al. 1999; Bauer et al. 2002), as well as fear learning and extinction (Bauer et al. 2002; Cain et al. 2002; Davis and Bauer 2012). Specifically, studies investigating the role of LVGCCs in fear learning have found that intra-amygdala infusions of the LVGCC antagonist, verapamil, prior to fear conditioning to a context or tone,

\footnotetext{
(C) 2017 Temme and Murphy This article is distributed exclusively by Cold Spring Harbor Laboratory Press for the first 12 months after the full-issue publication date (see http://learnmem.cshlp.org/site/misc/terms.xhtml). After 12 months, it is available under a Creative Commons License (AttributionNonCommercial 4.0 International), as described at http://creativecommons. org/licenses/by-nc/4.0/.
} 
prevented the acquisition and consolidation of the learned fear (Bauer et al. 2002). Additionally, studies using systemic or intraamygdala infusions of the LVGCC antagonists, verapamil, nifedipine, and nimodipine, found that blockade of LVGCCs can produce deficits in fear extinction (Cain et al. 2002; Davis and Bauer 2012).

Despite numerous studies demonstrating a clear role of LVGCCs in fear learning and extinction, the specific identity of the LVGCC subtypes involved is unclear. Of the four LVGCC subtypes expressed throughout the body, $\mathrm{Ca}_{V} 1.2$ and $\mathrm{Ca}_{V} 1.3$ are known to be abundantly expressed within the brain (Hell et al. 1993; Sinnegger-Brauns et al. 2009). While the $\mathrm{Ca}_{V} 1.2$ and $\mathrm{Ca}_{\mathrm{V}} 1.3$ subtypes share extensive similarities in structure and binding sites of LVGCC antagonists, substantial differences in activation voltages and inactivation rates (Xu and Lipscombe 2001) and neuronal distribution (Hell et al. 1993) suggest important differences in $\mathrm{Ca}_{V} 1.2$ and $\mathrm{Ca}_{V} 1.3$ function. Using a mouse in which Cacna1d (the gene that encodes $\mathrm{Ca}_{\mathrm{V}} 1.3$ ) was deleted, it was determined that Cav1.3 was required for the consolidation of conditioned fear, but not fear acquisition or fear extinction (McKinney and Murphy 2006). However, when similar studies were performed using mice in which $\mathrm{Ca}_{\mathrm{V}} 1.2$ was conditionally deleted in excitatory forebrain neurons using a CaMKII $\alpha$ Cre-driver line, no deficits were observed, suggesting that $\mathrm{Ca}_{\mathrm{V}} 1.2$ was not necessary for the consolidation or extinction of learned fear (McKinney et al. 2008c). However, deletion of $\mathrm{Ca}_{\mathrm{V}} 1.2$ in excitatory neurons alone, precluded the investigation of the potential role of $\mathrm{Ca}_{V} 1.2$ in the inhibitory circuits involved in fear extinction. While above-mentioned studies demonstrate a clear role of Cav1.3 in fear consolidation, due to the limited neuronal deletion pattern of the previously used $\mathrm{Ca}_{\mathrm{V}} 1.2$ conditional knockout mice, the potential role of $\mathrm{Ca}_{\mathrm{V}} 1.2$ in fear learning and extinction remains unclear.

In order to better understand the neuronal contribution of $\mathrm{Ca}_{\mathrm{V}} 1.2$ to fear learning and extinction, we crossed mice in which neuronal expression of Cre recombinase was driven by the synapsin 1 promoter (Zhu et al. 2001; Cui et al. 2008) with mice which have been engineered to have loxP sites flanking exon two of Cacna1c, the gene that encodes $\mathrm{Ca}_{\mathrm{V}} 1.2$ (White et al. 2008).

Using these $\mathrm{Ca}_{\mathrm{V}} 1.2$ conditional knockout mice, we found that panneuronal deletion of $\mathrm{Ca}_{\mathrm{V}} 1.2$ did not alter fear acquisition or consolidation to a tone or context. However, deletion of $\mathrm{Ca}_{\mathrm{V}} 1.2$ did produce a significant deficit in fear extinction to a conditioned context. To investigate the neurophysiological consequences of deleting $\mathrm{Ca}_{\mathrm{V}} 1.2$ within the amygdala, we recorded spontaneous inhibitory postsynaptic currents (sIPSCs) and spontaneous excitatory postsynaptic currents (sEPSCs) in principle neurons within the lateral amygdala. We found that pan-neuronal deletion of $\mathrm{Ca}_{\mathrm{V}} 1.2$ led to a shift in the balance of sIPSC and sEPSC activity by increasing the sIPSC frequency and reducing both the frequency and amplitude of sEPSCs. Taken together, our data suggest that $\mathrm{Ca}_{\mathrm{V}} 1.2$ is not only necessary for the extinction of a conditioned fear, but that deletion of $\mathrm{Ca}_{\mathrm{V}} 1.2$ produces an imbalance in the synaptic regulation of lateral amygdala activity. Understanding the contribution of
$\mathrm{Ca}_{\mathrm{V}} 1.2$ in fear extinction and amygdala excitability could lead to a better understanding of the neurophysiological underpinnings of trauma and anxiety-related disorders and may lead to improvements in extinction-based treatments such as exposure therapy.

\section{Results}

Prior to studying the effects of deletion of $\mathrm{Ca}_{\mathrm{V}} 1.2$ on fear learning and extinction, we first sought to determine whether panneuronal deletion of $\mathrm{Ca}_{\mathrm{V}} 1.2$ alters anxiety-like behavior. Alterations in basal anxiety have been previously observed with the use of L-type voltage-gated calcium channel antagonists (Matsumoto et al. 1994; El Ganouni et al. 1998) and thus could potentially confound the study of learned fear. To study basal anxiety-like behavior, we utilized the open field and light-dark box tests. During the open field test, mice were placed in a large arena where the well-lit center of the maze represents an anxiety provoking stimulus compared with the sheltered perimeter. Mice were placed individually in the center of the arena and monitored for a period of $5 \mathrm{~min}$. Analysis of the percent of time spent in the center of the maze revealed no alterations in anxiety-like behavior in $\mathrm{Ca}_{\mathrm{V}} 1.2$ conditional knockout mice compared with wild-type mice ( $P=0.42$ unpaired $t$-test) (Fig. 1A). As a measure of overall locomotor performance, total distance traveled within the arena was compared between genotypes (Fig. 1B). Analysis of the total distance traveled between genotypes found no significant difference $(P=0.96)$. Twenty-four hours after being tested in the open field, mice were tested for basal anxiety using the light-dark box test. In the light-dark box test, mice were placed in a chamber consisting of a well-lit open arena attached to an enclosed dark arena for 5 min. Mice were assessed for the percent of time spent in the light arena (Fig. 1C), as well as the number of transitions between the
A
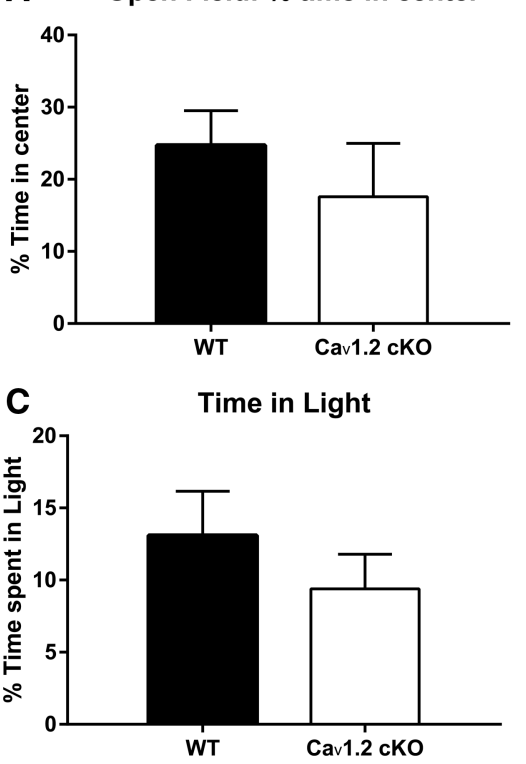

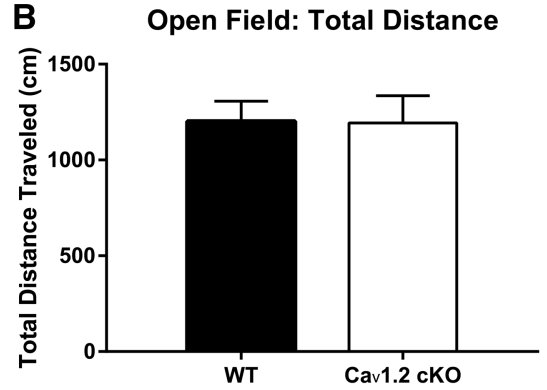

D

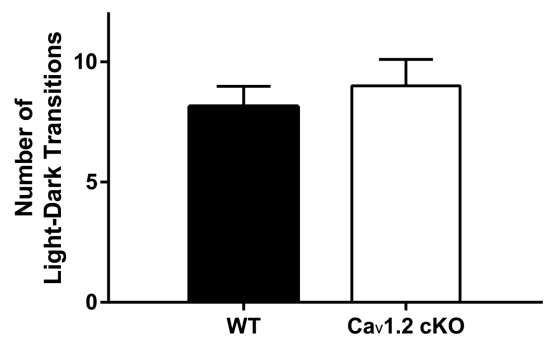

Figure 1. $C a_{v} 1.2$ conditional knockout mice exhibit normal basal anxiety and locomotion. Mice were tested for alterations in basal anxiety-like behavior using the open-field test and light-dark box test. $(A)$ In the open field test, $\mathrm{Ca}_{\mathrm{V}} 1.2$ conditional knockout mice $(n=12)$ spent a similar amount of time in the center of the open arena as their wild-type $(n=28)$ littermates. (B) Cav1.2 conditional knockout and wild-type mice also travelled a comparable distance within the arena throughout the open-field test. (C) In the light-dark box test, the Cav1.2 conditional knockout mice spent equivalent amounts of time in the light portion of the chamber as wild-type mice. (D) Similarly, Cav 1.2 conditional knockout mice and wild-type mice made a comparable number of transitions between the light and dark portions of the light-dark test. Data are represented as mean \pm SEM. 
light and dark compartments (Fig. 1D). Analysis of both the percent of time spent in the light arena and the number of transitions between light and dark compartments revealed no significant difference in genotype in either category $(P=0.56$ and $P=0.46$, respectively). The above results suggest that pan-neuronal deletion of $\mathrm{Ca}_{\mathrm{V}} 1.2$ does not alter basal anxiety.

To determine whether pan-neuronal deletion of $\mathrm{Ca}_{\mathrm{V}} 1.2$ altered fear acquisition or consolidation, we fear conditioned $\mathrm{Ca}_{\mathrm{V}} 1.2$ conditional knockout mice to a tone, as well as a context, and analyzed freezing levels throughout training and during tone and context tests. Mice were fear conditioned using one training session per day for $2 \mathrm{~d}$. During training, mice were given $3 \mathrm{~min}$ of context exposure in the conditioning chamber followed by three tone presentations, each which coterminated with a 2 -sec footshock. Tone-shock presentations were separated by $30 \mathrm{sec}$ with an additional $30 \mathrm{sec}$ after the final tone presentation. Acquisition of fear to the tone was analyzed across training as an average percent freezing to the tone for each training day (Fig. 2A). Analysis of tone freezing found no significant effect of genotype $\left(F_{(1,38)}=1.024, P=0.32\right)$ but a significant effect of training day $\left(F_{(1,38)}=164.895, P<0.0001\right)$. Acquisition of fear to the trained context was also assessed across training days as an average of the 3 min of context exposure for each conditioning day (Fig. 2B). Analysis of context freezing across training found no significant difference between genotypes $\left(F_{(1,38)}=0.076, P=0.7842\right)$ but a significant effect of training $\left(F_{(1,38)}=140.253, P<0.0001\right)$. Twentyfour hours after the last day of training, mice were tested for freezing to the tone in a novel context. Tone testing consisted of $1 \mathrm{~min}$ of context exposure followed by five tone alone presentations separated by $30 \mathrm{sec}$. Freezing to the tone was assessed as an average percent freezing across all tone presentations (Fig. 2C). Comparison of the average percent freezing to the tone between genotypes found no significant differences between $\mathrm{Ca}_{\mathrm{V}} 1.2$ conditional knockout mice and their wild-type counterparts $\left(F_{(1,38)}=0.567, P=0.4561\right)$ but a significant effect of tone presentation $\left(F_{(1,38)}=79.88, P<\right.$ $0.0001)$. Seventy-two hours after tone testing, mice were tested for their fear to the conditioned context using 5 min of context exposure to the trained context. Comparison of the average percent freezing during context testing revealed no significant difference between genotypes $(P=0.67)$ (Fig. $2 D)$. These studies suggest that pan-neuronal deletion of $\mathrm{Ca}_{\mathrm{V}} 1.2$ does not alter consolidation and express of conditioned fear.

To determine whether pan-neuronal deletion of $\mathrm{Ca}_{\mathrm{V}} 1.2$ alters extinction of a conditioned fear, $\mathrm{Ca}_{\mathrm{V}} 1.2$ conditional knockout mice $(n=14)$ and wild-type mice $(n=20)$ were conditioned to a context across $2 \mathrm{~d}$. Each day mice were given 3 min of context exposure followed by one unsignaled footshock $(0.5 \mathrm{~mA}, 2 \mathrm{sec})$. Conditioned freezing to the training context was plotted across training days using the average percent freezing of the 3-min context exposure each day (Fig. 3A). Analysis of the percent freezing revealed a significant effect of training $\left(F_{(1,32)}=75.354, P<0.0001\right)$, but no main effect of genotype $\left(F_{(1,32)}=1.585, P=0.22\right)$. Twentyfour hours after training mice were split into extinction and no extinction groups. Freezing to the trained context was extinguished using $2 \mathrm{~h}$ of context exposure, $1 \mathrm{~h}$ of context exposure per day for $2 \mathrm{~d}$, while mice who did not receive extinction remained in their home cages. Extinction training was plotted as an average percent freezing per 10-min bins, with bins one through six representing extinction day one and bins 7-12 representing extinction day two (Fig. 3B). Analysis of freezing within extinction days found a significant effect of extinction training on day one $\left(F_{(5,80)}=\right.$ 5.343, $P=0.0003)$ and day two $\left(F_{(5,80)}=2.577, P=0.0331\right)$, but no effect of genotype on either day (day one: $F_{(1,16)}=0.028, P=$ 0.870 and day two: $\left.F_{(1,16)}=0.118, P=0.7361\right)$. Twenty-four hours after extinction training, mice in the extinction and no extinction groups were tested for their fear to the conditioned context (Fig. 3C,D). Comparison of freezing levels before ("Pre" in Fig. 3C) and after extinction ("Post" in Fig. 3C) using a two-way repeated-measures ANOVA revealed a significant interaction between the genotype and extinction factors $\left(F_{(1,15)}=\right.$ $8.03, P=0.0126)$. In contrast to the wildtype mice, which exhibited significant levels of extinction $(P=0.0089$; paired $t$-test), mice that lacked $\mathrm{Ca}_{\mathrm{V}} 1.2$ exhibited no extinction $(P=0.888$; paired $t$-test $)$. Furthermore, the wild-type mice that where repeatedly exposed to the training context exhibited significantly less freezing when compared with wild-type mice that had not undergone extinction training (Fig. 3D; unpaired $t$-test, $P=0.0194$ ). This is in contrast to the $\mathrm{Ca}_{\mathrm{V}} 1.2$ conditional knockout mice that exhibited similar levels of freezing regardless of whether they were re-exposed to the training context or remained in their home cage (Fig. 3D; unpaired $t$-test, $P=$ 0.2713).

These data suggest that panneuronal deletion of $\mathrm{Ca}_{\mathrm{V}} 1.2$ leads to a deficit in extinction to a previously conditioned context. This supports previous pharmacological work suggesting an important role of L-type voltage-gated calcium channels in fear extinction (Blair et al. 2001; Bauer et al. 2002; Davis and Bauer 2012). Taken together with 

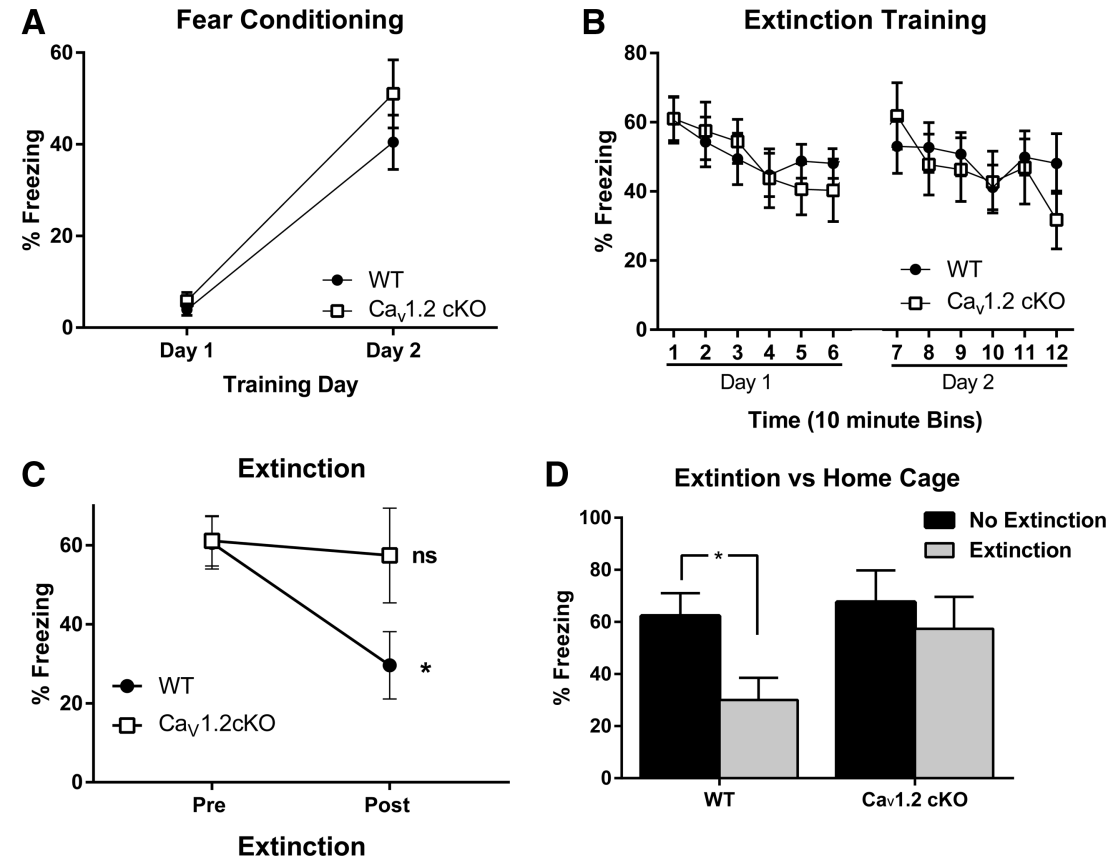

Figure 3. Cav1.2 conditional knockout mice exhibit significant deficits in fear extinction to a conditioned context. Mice were fear conditioned to a context using $3 \mathrm{~min}$ of context exposure followed by one unsignaled footshock presentation per day for $2 \mathrm{~d}$. Mice were then randomly assigned to extinction ( $n=7$ and 10 for Cav1.2 conditional knockout and wild-type, respectively) or no extinction ( $n=7$ and 10 for $\mathrm{Ca}_{\mathrm{v}} 1.2$ conditional knockout and wild-type, respectively) groups. Mice in the extinction group were extinguished using $2 \mathrm{~h}$ of context exposure split across $2 \mathrm{~d}$. Following extinction, both extinction and no extinction mice were assessed for fear to the conditioned context during the extinction test. (A) Cav1.2 and wild-type mice showed similar fear acquisition across context training days. (B) During context extinction, Cav1.2 conditional knockout and wild-type mice exhibit within session extinction in extinction day one, represented as time bins 1-6 and extinction day two, represented as time bins 7-12. (C) When tested $24 \mathrm{~h}$ after extinction training, wild-type mice exhibited significantly less freezing when compared with their own freezing levels on Extinction Day 1. In contrast, the Cav1.2 conditional knockout mice froze at levels that were statistically indistinguishable from their preextinction levels. $(D)$ When tested $24 \mathrm{~h}$ after extinction training, wild-type mice exhibited significantly less freezing when compared with wild-type mice that did not receive extinction training. Conversely, the Cav 1.2 conditional knockout mice exhibited similar levels of freezing regardless of whether they received the extinction training. Data are represented as mean \pm SEM. $\left({ }^{*}\right) P<0.05$.

previous studies showing normal fear extinction in mice lacking $\mathrm{Ca}_{\mathrm{V}} 1.2$ in excitatory neurons in the forebrain, but a significant decline in fear extinction with intra-amygdala infusions of LVGCC antagonists, we hypothesized that the deficit in fear extinction found in mice with a pan-neuronal deletion of $\mathrm{Ca}_{\mathrm{V}} 1.2$ is likely due to the role of these channels in inhibitory neuronal populations within the amygdala.

Previous reports have suggested a role for intra-amygdala inhibition of principle neurons in the lateral amygdala in mediating fear extinction (Likhtik et al. 2008; Lee et al. 2013; Trouche et al. 2013) leading us to hypothesize that deletion of $\mathrm{Ca}_{\mathrm{V}} 1.2 \mathrm{might}$ act to alter inhibition within the lateral amygdala. Electrophysiological recordings of sIPSCs were made using naïve $\mathrm{Ca}_{\mathrm{V}} 1.2$ conditional knockout and wild-type mice, 3-7 mo in age (Fig. 4A). Analysis of sIPSCs within the principle neurons of the lateral amygdala using a Kolmogorov-Smirnov test revealed a significant change in sIPSC interevent interval cumulative distribution between $\mathrm{Ca}_{\mathrm{V}} 1.2$ conditional knockout mice and wild-type mice $(P<$ 0.0001) (Fig. 4B). Spontaneous IPSC interevent interval distribution in $\mathrm{Ca}_{\mathrm{V}} 1.2$ conditional knockout mice can also be seen as a leftward shift from wild-type mice when assuming a Gaussian distribution (Fig. 4C). Analysis of spontaneous IPSCs using a Gaussian distribution predicted a mean of 2.795 and a variance of 0.5930 in wild-type mice and a mean of 2.656 and a variance of 0.6499 in $\mathrm{Ca}_{\mathrm{V}} 1.2$ conditional knockout mice. Finally, comparison of the average interevent interval of sIPSCs between genotypes using an unpaired $t$-test showed a significant increase in sIPSC frequency, seen as a decrease in interevent interval, compared with wild-type mice $(P=$ 0.0135) (Fig. 4D). However, comparison of the average sIPSC amplitude between genotypes using an unpaired $t$-test revealed no significant change $(P=0.46)$ (Fig. 4E). Along with producing significant deficits in the consolidation of fear extinction, pan-neuronal deletion of $\mathrm{Ca}_{\mathrm{V}}$ 1.2 significantly increases the frequency of spontaneous inhibitory activity onto principle neurons in the lateral amygdala, without altering the amplitude of these events. While increases in inhibition within the amygdala are more often linked to deficits in fear learning and expression, a correct balance of inhibitory and excitatory input is believed to be crucial for proper amygdala function.

To fully assess potential alterations in the balance of inhibitory and excitatory input in the amygdala in $\mathrm{Ca}_{\mathrm{V}} 1.2$ conditional knockout mice, we performed whole-cell voltage clamp recordings of spontaneous excitatory postsynaptic potentials onto principle neurons within the amygdala (Fig. 5A). Analysis of sEPSC interevent intervals using a Kolmogorov-Smirnov test found a significant difference in the sEPSC interevent interval cumulative distribution between $\mathrm{Ca}_{\mathrm{V}} 1.2$ conditional knockout mice and their wild-type counterparts $(P<0.0001)$ (Fig. 5B). This change in sEPSC interevent interval distribution was reflected as a rightward shift in the $\mathrm{Ca}_{\mathrm{V}} 1.2$ conditional knockout distribution compared with wild-type mice, assuming a Gaussian distribution (Fig. 5C). Analysis of sEPSC interevent intervals using a Gaussian distribution predicted a mean of 2.968 and a variance of 0.5408 in wildtype mice and a mean of 3.102 and a variance of 0.6574 in $\mathrm{Ca}_{\mathrm{V}} 1.2$ conditional knockout mice. Comparison of the average interevent interval between genotypes using an unpaired $t$-test further supported an increase in interevent interval in $\mathrm{Ca}_{\mathrm{V}} 1.2$ conditional knockout mice $(P=0.003)$ (Fig. 5D). Comparison of the average sEPSC amplitude between genotypes using an unpaired $t$-test also found a significant decrease in sEPSC size in $\mathrm{Ca}_{\mathrm{V}} 1.2$ conditional knockout mice compared with their wild-type counterparts (Fig. 5E). These data further support the hypothesis of altered inhibitory and excitatory balance in the lateral amygdala produced through neuronal deletion of $\mathrm{Ca}_{\mathrm{V}} 1.2$.

\section{Discussion}

Using a conditional Cacna1c knockout mouse line crossed with mice expressing Cre recombinase under the control of a synapsin 1 promoter, we assessed the impact of pan-neuronal deletion of $\mathrm{Ca}_{\mathrm{V}} 1.2$ in basal anxiety, fear learning, extinction, and network dynamics pyramidal cells in the lateral amygdala. Our studies reveal that pan-neuronal deletion of $\mathrm{Ca}_{\mathrm{V}} 1.2$ did not alter basal anxiety 
A1

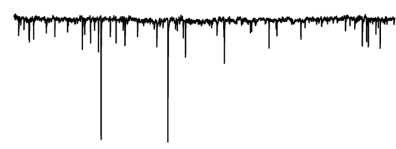

造

A2

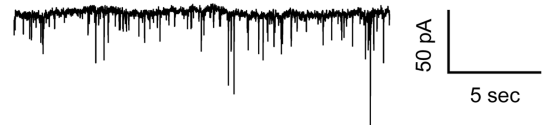

C1

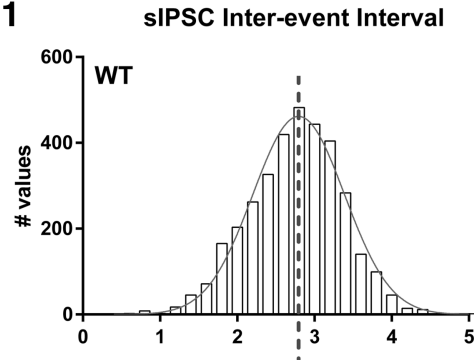

C2

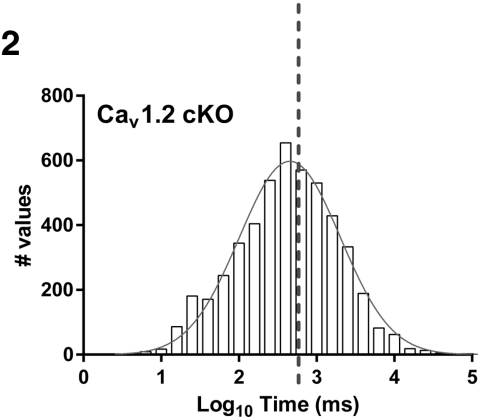

B

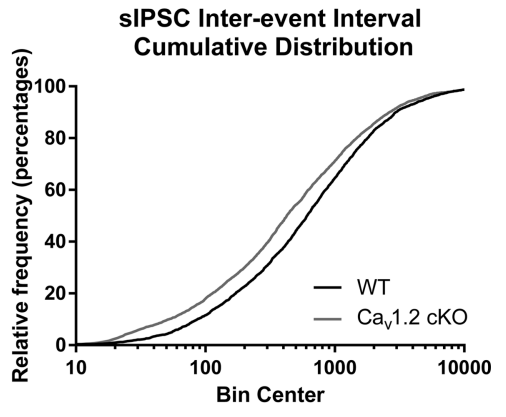

D

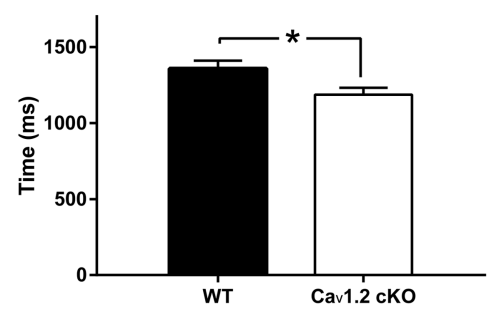

E

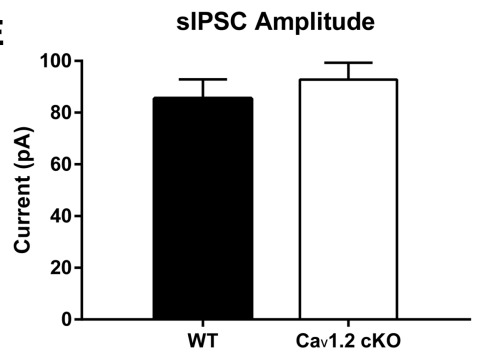

Figure 4. Neuronal deletion of Cav1.2 results in an increase in sIPSC activity in principle neurons of the lateral amygdala. Representative recordings from wild-type $\left(A_{1}\right)$ and $\mathrm{Ca}_{\mathrm{v}} 1.2$ conditional knockout mice $\left(A_{2}\right)$ of spontaneous IPSCs in inhibition onto principle neurons of the lateral amygdala using whole-cell voltage clamp. (B) Cav1.2 conditional knockout mice exhibited a significant change in sIPSC interevent interval cumulative distribution compared with wild-type mice. $\left(C_{1}, C_{2}\right)$ Representation of the sIPSC interevent intervals using a histogram and a fitted Gaussian distribution, showed a leftward shift in $\mathrm{Ca}_{\mathrm{v}} 1.2$ conditional knockout interevent intervals compared with wild-type mice. $(D, E)$ Cav1.2 conditional knockout mice exhibited a significant decrease in the average sIPSC $(n=4884$ events in 23 cells from seven mice) interevent interval compared with wild-type littermates ( $n=3442$ events in 19 cells from six mice), but no change in sIPSC amplitude. Data are represented as mean \pm SEM. $\left({ }^{*}\right) P<0.05$.

or fear learning and consolidation. However, deletion of $\mathrm{Ca}_{\mathrm{V}} 1.2$ leads to significant deficits in the extinction of conditioned fear that was not observed in previous studies using other Cre-driver lines to ablate $\mathrm{Ca}_{\mathrm{V}} 1.2$. In addition, pan-neuronal deletion of $\mathrm{Ca}_{\mathrm{V}} 1.2$ altered sIPSC and sEPSC activity within the amygdala, producing a shift in the inhibitory/excitatory balance onto principle neurons in the lateral amygdala.

In order to understand the potential role of $\mathrm{Ca}_{\mathrm{V}} 1.2$ in fearrelated learning, we tested whether pan-neuronal deletion of $\mathrm{Ca}_{\mathrm{V}} 1.2$ leads to an increase in basal anxiety-like behavior independent of learned fear. When examined in the open-field test and light-dark box test, no changes in basal anxiety-like behavior were noted in the $\mathrm{Ca}_{\mathrm{V}} 1.2$ conditional knockout mice. When $\mathrm{Ca}_{\mathrm{V}} 1.2$ conditional knockout mice were examined in the openfield test, they exhibited equal amounts of time in the open, center portion of the arena as their wild-type littermates. Similarly, when $\mathrm{Ca}_{\mathrm{V}} 1.2$ conditional knockout mice were observed in the light-dark box test, they spent similar quantities of time in the light side of the arena compared with their wild-type counter parts. These results were further supported by the analysis of locomotion during each test demonstrating roughly equal amount of distance traveled in the open-field test and number of light-dark arena transitions in the light-dark box test suggesting normal motor capability and anxiety within $\mathrm{Ca}_{\mathrm{V}} 1.2$ conditional knockout mice. These data suggest that pan-neuronal deletion of $\mathrm{Ca}_{\mathrm{V}} 1.2$ does not alter basal anxiety-like behavior. Interestingly, previous studies have provided conflicting results pertaining to the role of $\mathrm{Ca}_{\mathrm{V}} 1.2$ and LVGCCs in the regulation of anxiety-like behaviors. While decreases in anxiety-like behavior has been noted in rats with intracerebroventricular injections of the LVGCC antagonist verapamil (Matsumoto et al. 1994; El Ganouni et al. 1998), forebrain-specific and prefrontal cortex-specific deletion of $\mathrm{Ca}_{\mathrm{V}} 1.2$ in mice resulted in an increase in anxiety-like behaviors (Lee et al. 2012). Discrepancies between our results and previously published results could be due to the well documented nonspecific effects of LVGCC antagonists (Das et al. 2004; Edraki et al. 2009; Thompson et al. 2011) or the effect of deletion of $\mathrm{Ca}_{V} 1.2$ on a different genetic background (Crawley et al. 1997; Temme et al. 2014). Substantial differences in various transgenic mouse lines have been noted using difference mouse strains (Bergren et al. 2005; Abdolvahab et al. 2014; Dorà et al. 2014). Despite potential discrepancies in anxiety-like behavior related to LVGCCs, the lack of an anxiety-related phenotype in our mice leads us to conclude that any differences in fear-related learning in our $\mathrm{Ca}_{\mathrm{V}} 1.2$ conditional knockout mice are likely due to the effect of deletion of $\mathrm{Ca}_{\mathrm{V}} 1.2$ in fear-related circuits rather than a change in basal anxiety.

In addition to the conflicting literature pertaining to the role of LVGCCs in basal anxiety, studies of LVGCCs have found mixed results regarding the role of these channels in fearrelated learning. Pharmacological studies have implicated deficits in both fear learning as well as fear extinction in the presence of systemic and intra-amygdala infusions of LVGCC antagonists (Bauer et al. 2002; Cain et al. 2002; Davis and Bauer 2012). Previous studies using a whole-body (global) $\mathrm{Ca}_{\mathrm{V}} 1.3$ knockout found that genetic ablation of $\mathrm{Ca}_{\mathrm{V}} 1.3$ disrupted consolidation of contextual fear conditioning while leaving fear extinction learning intact (McKinney and Murphy 2006). In contrast, conditional $\mathrm{Ca}_{V} 1.2$ knockout mice in which the deletion pattern was restricted to glutamatergic neurons in the forebrain exhibited no deficits in the acquisition, consolidation, or extinction of contextual fear memories (McKinney et al. 2008c).

In the current study, $\mathrm{Ca}_{\mathrm{V}} 1.2$ conditional knockout mice with pan-neuronal deletion of $\mathrm{Ca}_{\mathrm{V}} 1.2$ displayed normal fear acquisition, consolidation, and expression. When fear conditioned, $\mathrm{Ca}_{\mathrm{V}} 1.2$ conditional knockout mice and their wild-type counterparts showed similarly high levels of freezing when tested 
A1
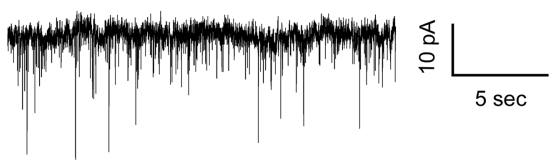

A2

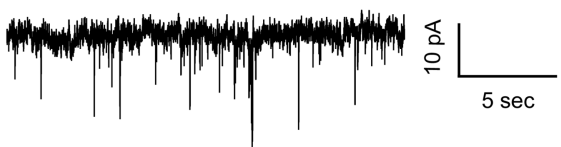

C1 sEPSC Inter-event Interval

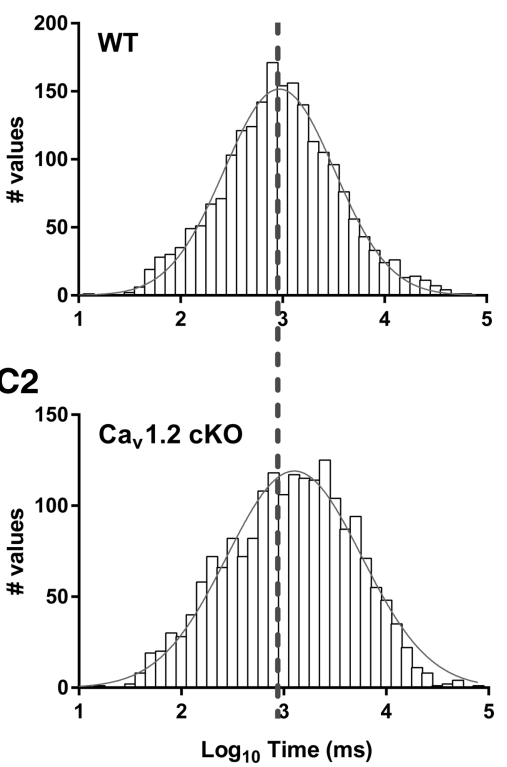

B

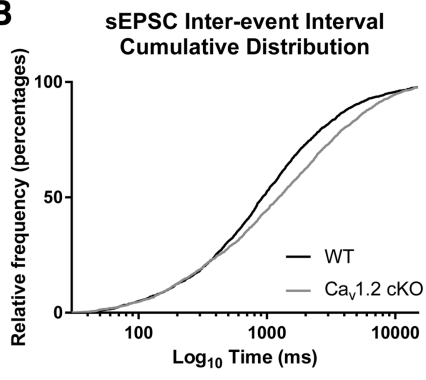

D

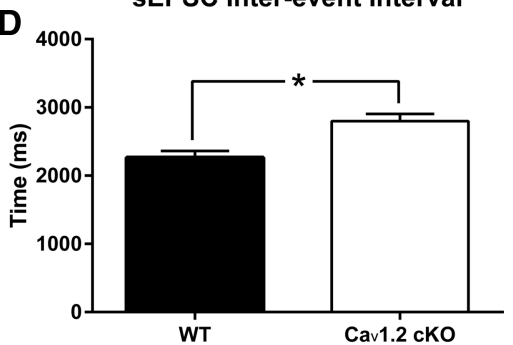

E

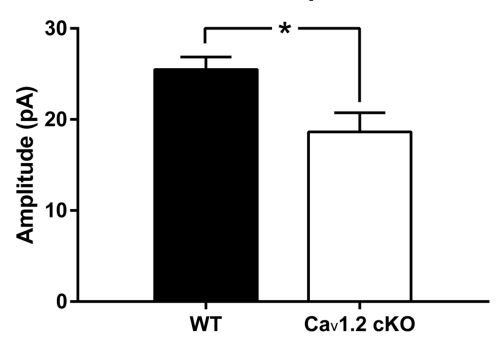

Figure 5. Neuronal deletion of $\mathrm{Ca}_{\mathrm{v}} 1.2$ results in an increase in SEPSC interevent interval and a decrease in SEPSC amplitude in principle neurons in the lateral amygdala. Representative recordings from wildtype $\left(A_{1}\right)$ and $\mathrm{Ca}_{\mathrm{V}} 1.2$ conditional knockout mice $\left(A_{2}\right)$ of spontaneous EPSCs in inhibition onto principle neurons of the lateral amygdala using whole-cell voltage clamp. (B) Representation of the sEPSC interevent interval as a cumulative distribution with a significant difference in the Kolmogorov-Smirnov test between Cav1.2 conditional knockout and wild-type mice. $\left(C_{1}, C_{2}\right)$ Representation of the sEPSC interevent intervals using a histogram, and a fitted Gaussian distribution shows a rightward shift in Cav1.2 conditional knockout interevent interval compared with wild-type mice. (D) Cav1.2 conditional knockout mice exhibited a significant increase in the average sEPSC $(n=1927$ events in 20 cells from six mice) interevent interval compared with wild-type littermates ( $n=2094$ events in 16 cells from six mice). $(E)$ $\mathrm{Ca}_{v} 1.2$ conditional knockout mice also showed a significant decrease in the average size of the sEPSCs. Data are represented as mean \pm SEM. $\left(^{*}\right) P<0.05$.

for their fear to either the context or tone. These results are consistent with previous reports that $\mathrm{Ca}_{\mathrm{V}} 1.2$ deletion does not alter the consolidation of fear memories (McKinney et al. 2008c; Langwieser et al. 2010). However, $\mathrm{Ca}_{\mathrm{V}} 1.2$ conditional knockout mice failed to show a reduction in fear response to a conditioned context after extinction training. When mice underwent extinction of the conditioned context, $\mathrm{Ca}_{\mathrm{V}} 1.2$ conditional knockout extinction mice displayed a high level of freezing to the conditioned context, with no notable difference in freezing between mice that received extinction training and mice that did not. Interestingly, this deficit in context extinction was observed during extinction testing and across extinction days, but not during within session extinction training. These data confirm previously published literature indicating a role of LVGCCs in fear extinction (Bauer et al. 2002; Cain et al. 2002; Davis and Bauer 2012), as well as the theory that LVGCCs effect the consolidation, but not the acquisition or expression of extinction learning (Davis and Bauer 2012). Taken together with previous studies showing normal extinction in ance in neuronal input onto principle neurons in the lateral amygdala. While one might predict deficits in fear extinction, such as those observed in the $\mathrm{Ca}_{\mathrm{V}} 1.2$ conditional knockout mice studied here, to be associated with a decrease in inhibition or enhanced excitation within the amygdala, we hypothesize that the shift in the inhibitory/excitatory input onto projection neurons in the lateral amygdala alters the homeostatic balance of activity within the amygdala which in turn disrupts extinction. The lateral amygdala is considered the input structure of the amygdala (Maren 1999, 2000; Jimenez and Maren 2009). Tight regulation of activity within this structure is vital for mediating fear memories (Lang and Paré 1997; Royer et al. 1999; Pare et al. 2003). Basal alterations of inhibitory tone within the LA and BLA have been shown to significantly change the activity pattern in the amygdala producing distinct differences in amygdala-associated behaviors. In fact, reductions in local inhibition within the amygdala have been demonstrated to produce nonassociative and generalized fear expression (Shaban et al. 2006; Bergado-Acosta et al. 2008; Wiltgen et al. 2009). 
Similarly, increases in inhibition have been found to alter the firing activity of neurons within the amygdala (Royer et al. 1999; Pare et al. 2003). Enhanced activity of inhibitory interneurons within the amygdala has been associated with a reduced probability of long-term plasticity induction at the thalamo-amygdala pathway (Bissière et al. 2003). Additionally, firing of inhibitory interneurons within the basolateral amygdala has been found to inhibit spiking of pyramidal neurons (Lang and Paré 1997) and alters synchronized firing of principle neurons in the amygdala (Woodruff and Sah 2007). In fact, changes in sEPSCs frequency and amplitude, such as those seen in our studies, could be due to an increase in inhibitory input onto the excitatory afferents that form synapses onto principle neurons in the amygdala. Additionally, while increases in inhibitory/excitatory balance are not normally tied to the extinction of fear, the exact neurons that are altered by the shift in inhibition may matter in mediating fear behavior. For example, some excitatory cells in the BLA have been observed to decrease their firing in response to a fearful stimulus after extinction. Other excitatory cells, such as extinction cells, do not show an alteration in firing rates in the presence of fear conditioning, but do show an increased rate of activity upon fear extinction (Herry et al. 2008).

Given the complex interaction between inhibitory/excitatory input onto lateral amygdala neurons and amygdala related behavior and plasticity, more information would need to be gathered to understand how an increase in inhibitory/excitatory balance could produce deficits in fear extinction. In order to address this question in the $\mathrm{Ca}_{\mathrm{V}} 1.2$ conditional knockout mice, additional studies would need to be performed to investigate the source of enhanced sIPSC activity in projection neurons within the lateral amygdala, whether it originates from external regions associated with fear extinction, such as the prefrontal cortex and hippocampus, or from within the amygdala itself. Similarly, additional studies will need to be completed to determine the source of the altered sEPSC activity within the lateral amygdala, as well as whether the changes in sEPSC activity are due to the loss of $\mathrm{Ca}_{\mathrm{V}} 1.2$ within excitatory neurons that synapse onto principle neurons in the amygdala, or due to an increase in inhibitory input onto these excitatory afferents. Finally, more complex studies to identify the types of neurons, such as those that fire in response to fear learning or to extinction learning, that are altered by the change in inhibitory/excitatory balance, could help in the identification of the $\mathrm{Ca}_{V} 1.2$-mediated neural circuitry involved in fear extinction.

In conclusion, our work has clearly identified a role of the LVGCC subtype, $\mathrm{Ca}_{\mathrm{V}} 1.2$ in fear extinction. In addition to altering fear extinction, pan-neuronal deletion of $\mathrm{Ca}_{\mathrm{V}} 1.2$ was also found to significantly alter the sIPSC/sEPSC balance of activity onto principle projection neurons within the lateral amygdala. We postulate that this imbalance in activity produces significant alterations in amygdala function and output, thereby altering fear extinction in a $\mathrm{Ca}_{\mathrm{V}} 1.2$-dependent manner.

\section{Materials and Methods}

\section{Mice}

For all experiments, $\mathrm{Ca}_{\mathrm{v}} 1.2$ conditional knockout mice with neuron specific deletion of $\mathrm{Ca}_{\mathrm{V}} 1.2$ and their wild-type littermates were used. Mice used in these studies were on a B57Bl/6:129SvEv F2 genetic background. Mice with a floxed $\mathrm{Ca}_{V} 1.2$ exon two allele $\left(\mathrm{Ca}_{\mathrm{V}} 1.2^{\mathrm{f} /+}\right.$ or $\left.\mathrm{Ca} \mathrm{V}_{\mathrm{V}} 1.2^{\mathrm{f} / \mathrm{f}}\right)$ and maintained on a $129 \mathrm{SvEv}$ genetic background (White et al. 2008) were first bred to transgenic mice expressing the Cre recombinase regulated by the synapsin 1 promoter (Syn1-Cre ${ }^{\mathrm{Cre} /+}$ ) and maintained on a C57BL/6 background (Zhu et al. 2001; Cui et al. 2008), producing an F1 cross. Using nonlittermate offspring from the F1 cross, heterozygous floxed, cre-positive $\left(\mathrm{Ca}_{\mathrm{V}} 1.2^{\mathrm{f} /+}\right.$; Syn1-Cre $\left.{ }^{\mathrm{Cre} /+}\right)$ mice were then crossed with heterozygous floxed, cre-negative $\left(\mathrm{Ca}_{\mathrm{V}} 1.2^{\mathrm{f} /+}\right.$; Syn1-Cre ${ }^{+/+}$) mice to produce homozygous floxed, Cre-positive $\left(\mathrm{Ca}_{\mathrm{V}} 1.2^{\mathrm{f} / \mathrm{f}} ;\right.$ Syn1-Cre $\left.{ }^{\mathrm{Cre} /+}\right)$ conditional knockout mice. Consistent with previous reports (Zhu et al. 2001; Cui et al. 2008) recombination using the Syn1-Cre ${ }^{\mathrm{Cre} /+}$ mice was highly efficient with $\mathrm{Ca}_{\mathrm{V}} 1.2$ minimally detectable by Western blot analysis of whole-brain lysates (Buonarati et al. 2017). In addition to the true knockout mice breeding also resulted in offspring that were categorized as wild-type or control. Mice were considered wild-type if they were Cre positive, but lacked the floxed alleles $\left(\mathrm{Ca}_{\mathrm{V}} 1.2^{+/+}\right.$; Syn1-Cre ${ }^{+/}$ $\left.{ }^{+}\right)$. Mice were considered control if they were homozygous or heterozygous for the floxed allele and cre negative (i.e., $\mathrm{Ca}_{\mathrm{V}} 1.2^{\mathrm{f} / \mathrm{f}}$; Syn1-Cre ${ }^{+/+}$or $\mathrm{Ca}_{\mathrm{V}} 1.2^{\mathrm{f} /+}$; Syn1-Cre $\left.{ }^{+/+}\right)$, or if they were cre positive but lacked the floxed alleles $\left(\mathrm{Ca}_{\mathrm{V}} 1.2^{+/+}\right.$; Syn1-Cre $\left.{ }^{\mathrm{Cre} /+}\right)$. For every experiment, true wild-type mice were initially compared with the control groups. In the absence of any meaningful differences or interactions these groups were collapsed into a single group (see Supplemental Table 1). This collapsed group is termed wild-type from here after.

Studies were conducted using mice that were 3-7 mo old at the time of testing or slice preparation. Approximately equal numbers of males and females were used. No significant differences were found between males and females throughout experimentation. Mice were housed by sex in groups of three to five mice. Mice were kept in micro-isolation cages with a 14 -h/10-h lightdark cycle with an average ambient temperature of $22^{\circ} \mathrm{C}$ and ad libitum food and water. All experiments were conducted during the designated light phase according to the National Institute of Health guidelines for animal care and were approved by the University Committee on the Use and Care of Animals of the University of Michigan.

\section{Behavioral procedures}

Two cohorts of mice were used for the behavioral experiments. One cohort of mice underwent the open-field test, the light-dark box test, and fear conditioning to a context and tone, in that order, separated by $24 \mathrm{~h}$. Another cohort of mice was fear conditioned and subsequently tested for contextual fear extinction.

\section{Open field}

The open-field experiment was performed in a large white acrylic chamber $(71 \times 71 \times 30 \mathrm{~cm})$ with indirect white light and a light level of 200 lux at the center of the chamber. During testing, naive mice were placed in the center of the chamber and allowed to explore for $5 \mathrm{~min}$. Mice were tracked throughout the chamber using Limelight software by Actimetrics. Tracking data were analyzed offline with the open-field chamber divided into an $8 \times 8$ grid with a center zone of $53.25 \mathrm{~cm} \times x 53.25 \mathrm{~cm}$ and an outer zone of $8.875 \mathrm{~cm}$ around the border. Mouse performance was analyzed for total distance traveled and percent time in the center.

\section{Light-dark box}

The light-dark box consisted of an acrylic chamber $(26.5 \mathrm{~cm} \times 46$ $\mathrm{cm} ; \mathrm{W} \times \mathrm{L}$ ) with the exposed light portion (200 lux at the center of the light compartment) made of white acrylic and an enclosed dark portion composed of black acrylic which was half the length of the light chamber (McKinney et al. 2008a,b). During testing, mice were placed individually in the center of the light compartment and were allowed to explore for a period of $5 \mathrm{~min}$. Mice were tracked using Limelight by Actimetrics. Tracking data were analyzed offline and the time spent in the light compartment and the number of light dark transitions was computed.

\section{Fear conditioning and extinction}

Fear conditioning experiments were carried out as previously described (Temme et al. 2014). Mice were trained in fear conditioning chambers with clear acrylic backs and doors, aluminum sides, stainless steel grid floors spaced $1 / 8$ in, and stainless steel drop pans (Med Associates). Chambers and floor pans were cleaned with $70 \%$ ethanol throughout experimentation and illuminated 
with white room lights $(150 \mathrm{~W})$. Shocks were administered through the grid via solid-state shock scramblers and electronic constant-current shock sources controlled by a desktop PC running Actimetrics, FreezeFrame software. The same computer and software were used to record behavior that was digitized using individual cameras mounted above each chamber. Mice were fear conditioned to a tone using two training sessions, one per day for $2 \mathrm{~d}$. During training, mice were exposed to the training context for $3 \mathrm{~min}$ followed by three tone-shock presentations in which a $30 \mathrm{sec}$ tone $(75 \mathrm{~dB}, 2.8 \mathrm{kHz})$ coterminated with a $2 \mathrm{sec}$ footshock $(0.65 \mathrm{~mA}, 2 \mathrm{sec})$, with $30 \mathrm{sec}$ between tones. Mice remained in the conditioning chamber for $30 \mathrm{sec}$ following the last tone-shock pairing. Twenty-four hours after training mice were tested for their freezing behavior to the conditioned tone in a novel context (context B) consisting of smooth opaque white acrylic coverings over the floor and walls that produced the appearance of a semicircular chamber. The chamber and floor pans were cleaned with $2 \%$ acetic acid and red room lights $(60 \mathrm{~W})$ were used. During tone testing, mice were placed in context $\mathrm{B}$ followed by five tone alone presentations (30 sec) with $30 \mathrm{sec}$ between tones. Mice were removed from the chambers $30 \mathrm{sec}$ after the last tone presentation. Seventy-two hours after tone testing, mice were returned to the original training context (5 min). In all experiments, fear was assessed by measuring freezing, defined as a lack of motion, except that required for respiration, for $1 \mathrm{sec}$ or more and was calculated using a sensitive global motion-detection algorithm (FreezeFrame and FreezeView software; Actimetrics).

In experiments involving fear extinction, mice were exposed to the same context during a single session each day for $2 \mathrm{~d}$, with sessions consisting of 3 min of context exposure followed by one unsignaled footshock $(0.5 \mathrm{~mA}, 2 \mathrm{sec})$ and $30 \mathrm{sec}$ context exposure after the shock. After conditioning, mice were separated into extinction and no extinction groups. Twenty-four hours after training, mice in the extinction group were extinguished to their fear to the context using two 1-h sessions of context exposure, one per day for $2 \mathrm{~d}$. Twenty-four hours after the last extinction session, extinction and no extinction mice were tested for their fear to the context using $5 \mathrm{~min}$ of context exposure.

\section{Electrophysiology}

\section{Slice preparation}

Electrophysiology experiments utilized conditional knockout mice and true wild-type littermates. Mice (3-7 mo old) were deeply anesthetized with isoflurane prior to dissection. Brains were rapidly removed and incubated in an oxygenated, ice slurry of sucrose based cutting solution: (in $\mathrm{mM}$ ): 206.0 sucrose, $2.8 \mathrm{KCl}, 1.25 \mathrm{MgCl}_{2}$ $6 \mathrm{H}_{2} \mathrm{O}, 1.0 \mathrm{MgSO}_{4}, 1.25 \mathrm{NaH}_{2} \mathrm{PO}_{4}, 1.25 \mathrm{CaCl}_{2}, 10$ D-Glucose, 26 $\mathrm{NaHCO}_{3}, 0.4$ Ascorbic Acid, for a period of one to $2 \mathrm{~min}$. Brains were then bisected and placed in the slicing chamber with $1.5 \%$ agar blocks as support and submerged in ice-cold sucrose cutting solution. The brain tissue was sliced in a coronal plane through the amygdala at $300 \mu \mathrm{m}$. Slices were then incubated in room temperature oxygenated artificial cerebral spinal fluid (aCSF; in $\mathrm{mM}$ ): $124 \mathrm{NaCl}, 2.8 \mathrm{KCl}, 1 \mathrm{MgSO}_{4}, 1.25 \mathrm{NaH}_{2} \mathrm{PO}_{4}, 2.5 \mathrm{CaCl}_{2}, 10$ D-Glucose, $26.0 \mathrm{MaHCO}_{3}, 0.4$ ascorbic acid, for a minimum of 1 $\mathrm{h}$ prior to recording.

\section{Electrophysiological recordings}

Electrophysiology recordings were made using a Dagan 3900A integrating patch clamp amplifier and digitized using an Axon Instruments 1322A Digidata. Recordings were made using glass electrodes made from borosilicate glass with filament $(1.5 \mathrm{~mm} \times$ $0.86 \mathrm{~mm}$; Sutter Instruments) and a resistance between 4 to 8 $\mathrm{M} \Omega$. Principle neurons in the LA were visualized using standard IR/DIC optics to make whole-cell voltage clamp recordings of spontaneous inhibitory postsynaptic currents (sIPSCs) and spontaneous excitatory postsynaptic currents (sEPSCs). Spontaneous IPSC recordings were made using a cesium chloride internal solution (in mM): $130 \mathrm{CsCl}, 1.0 \mathrm{KCl}, 1.0 \mathrm{NaCl}, 1.0 \mathrm{MgCl}_{2}, 1.0 \mathrm{CaCl}_{2}, 10.0$ HEPES, 7.0 phosphocreatine, $4.0 \mathrm{Na}_{2} \mathrm{ATP}, 0.3$ TrisGTP, 0.2 EGTA,
$0.1 \%$ biocytin, in a submersion chamber with continuous aCSF perfusion $(\sim 1.5 \mathrm{~mL} / \mathrm{min})$ containing $4.0 \mathrm{mM}$ kynurenic acid (Sigma-Aldrich) and heated to $31^{\circ} \mathrm{C}$. Spontaneous EPSC recordings were made using cesium gluconate internal solution (in $\mathrm{mM}$ ): 100 cesium gluconate, 0.2 EGTA, $5 \mathrm{MgCl}_{2}$, 2 ATP, 0.3 GTP, 40 HEPES, $0.1 \%$ biocytin, and aCSF perfusion containing $20 \mu \mathrm{m}$ picrotoxin (Sigma-Aldrich). For both sIPSC and sEPSC experiments, the resting membrane potential was clamped at $-70 \mathrm{mV}$ and synaptic activity was recorded for a period of $5 \mathrm{~min}$. Recordings of sIPSCs and sEPSCs were analyzed offline using Mini Analysis (Synaptosoft).

\section{Statistical analysis}

Analysis of behavioral experiments was carried out using unpaired $t$-tests comparing $\mathrm{Ca}_{\mathrm{v}} 1.2$ conditional knockout mice with their wild-type counterparts. Learning across fear conditioning and extinction training was analyzed using a two-way ANOVA and repeated-measures ANOVA, respectively, with genotype and training as factors. Electrophysiological recordings of sIPSCs and sEPSCs frequency, as an interevent interval, were analyzed as a cumulative frequency distribution using the Kolmogorov-Smirnov test. Average interevent intervals and amplitudes between genotypes were also compared using an unpaired $t$-test.

\section{Acknowledgments}

This research was funded by the National Science Foundation, Graduate Research Fellowship to S.J.T., the Society of Neuroscience, Neuroscience Scholars Program Award to S.J.T., and NIA R01 AG028488. The authors declare no conflict of interest.

\section{References}

Abdolvahab MH, Brinks V, Schellekens H. 2014. A modified immune tolerant mouse model to study the immunogenicity of recombinant human interferon $\beta$. J Immunol Methods 415: 17-23.

American Psychiatric Association. 2013. Diagnostic and statistical manual of mental disorders: DSM-5.

Barad M. 2006. Is extinction of fear erasure or inhibition? Why both, of course. Learn Mem 13: 108-109.

Barad M, Gean P-W, Lutz B. 2006. The role of the amygdala in the extinction of conditioned fear. Biol Psychiatry 60: 322-328.

Bauer EP, Schafe GE, LeDoux JE. 2002. NMDA receptors and L-type voltage-gated calcium channels contribute to long-term potentiation and different components of fear memory formation in the lateral amygdala. J Neurosci 22: 5239-5249.

Bergado-Acosta JR, Sangha S, Narayanan RT, Obata K, Pape HC, Stork O. 2008. Critical role of the $65-\mathrm{kDa}$ isoform of glutamic acid decarboxylase in consolidation and generalization of Pavlovian fear memory. Learn Mem 15: 163-171.

Bergren SK, Chen S, Galecki A, Kearney JA. 2005. Genetic modifiers affecting severity of epilepsy caused by mutation of sodium channel Scn2a. Mamm Genome 16: 683-690.

Bissière S, Humeau Y, Lüthi A. 2003. Dopamine gates LTP induction in lateral amygdala by suppressing feedforward inhibition. Nat Neurosci 6: 587-592.

Blair HT, Schafe GE, Bauer EP, Rodrigues SM, LeDoux JE. 2001. Synaptic plasticity in the lateral amygdala: a cellular hypothesis of fear conditioning. Learn Mem 8: 229-242.

Buonarati OR, Henderson PB, Murphy GG, Horne MC, Hell JW. 2017. Proteolytic processing of the L-type $\mathrm{Ca}^{2+}$ channel $\alpha 11.2$ subunit in neurons. F1000Research: In press.

Cain CK, Blouin AM, Barad M. 2002. L-type voltage-gated calcium channels are required for extinction, but not for acquisition or expression, of conditional fear in mice. J Neurosci 22: 9113-9121.

Clapham DE. 2007. Calcium signaling. Cell 131: 1047-1058.

Crawley JN, Belknap JK, Collins A, Crabbe JC, Frankel W, Henderson N, Hitzemann RJ, Maxson SC, Miner LL, Silva AJ, et al. 1997. Behavioral phenotypes of inbred mouse strains: implications and recommendations for molecular studies. Psychopharmacology (Berl) 132: $107-124$.

Cui Y, Costa RM, Murphy GG, Elgersma Y, Zhu Y, Gutmann DH, Parada LF, Mody I, Silva AJ. 2008. Neurofibromin regulation of ERK signaling modulates GABA release and learning. Cell 135: 549-560. 
Das P, Bell-Horner CL, Huang RQ, Raut A, Gonzales EB, Chen ZL, Covey DF, Dillon GH. 2004. Inhibition of type A GABA receptors by L-type calcium channel blockers. Neuroscience 124: 195-206.

Davis SE, Bauer EP. 2012. L-type voltage-gated calcium channels in the basolateral amygdala are necessary for fear extinction. J Neurosci 32: 13582-13586.

Dorà NJ, Collinson JM, Hill RE, West JD. 2014. Hemizygous Le-Cre transgenic mice have severe eye abnormalities on some genetic backgrounds in the absence of LoxP sites. PLoS One 9: e109193.

Edraki N, Mehdipour AR, Khoshneviszadeh M, Miri R. 2009. Dihydropyridines: evaluation of their current and future pharmacological applications. Drug Discov Today 14: 1058-1066.

El Ganouni S, Tazi A, Hakkou F. 1998. Potential serotonergic interactions with the anxiolytic-like effects of calcium channel antagonists. Pharmacol Biochem Behav 60: 365-369.

Furini C, Myskiw J, Izquierdo I. 2014. The learning of fear extinction. Neurosci Biobehav Rev 47C: $670-683$

Garakani A, Mathew SJ, Charney DS. 2006. Neurobiology of anxiety disorders and implications for treatment. Mt Sinai J Med 73: 941-949.

Gordon D, Heimberg RG, Tellez M, Ismail AI. 2013. A critical review of approaches to the treatment of dental anxiety in adults. J Anxiety Disord 27: $365-378$.

Heldt SA, Ressler KJ. 2007. Training-induced changes in the expression of GABA(A)-associated genes in the amygdala after the acquisition and extinction of Pavlovian fear. Eur J Neurosci 26: 3631-3644.

Hell JW, Westenbroek RE, Warner C, Ahlijanian MK, Prystay W, Gilbert MM, Snutch TP, Catterall WA. 1993. Identification and differential subcellular localization of the neuronal class $\mathrm{C}$ and class D L-type calcium channel $\alpha 1$ subunits. J Cell Biol 123: 949-962.

Herry C, Ciocchi S, Senn V, Demmou L, Muller C, Luthi A. 2008. Switching on and off fear by distinct neuronal circuits. Nature 454: 600-606.

Hofmann SG. 2007. Cognitive processes during fear acquisition and extinction in animals and humans: implications for exposure therapy of anxiety disorders. Clin Psychol Rev 28: 199-210.

Jimenez SA, Maren S. 2009. Nuclear disconnection within the amygdala reveals a direct pathway to fear. Learn Mem 16: 766-768.

Kalish HI. 1954. Strength of fear as a function of the number of acquisition and extinction trials. J Exp Psychol 47: 1-9.

Lang EJ, Paré D. 1997. Similar inhibitory processes dominate the responses of cat lateral amygdaloid projection neurons to their various afferents. J Neurophysiol 77: 341-352.

Langwieser N, Christel CJ, Kleppisch T, Hofmann F, Wotjak CT, Moosmang S. 2010. Homeostatic switch in hebbian plasticity and fear learning after sustained loss of CaV1.2 calcium channels. J Neurosci 30: 8367-8375.

Lee AS, Ra S, Rajadhyaksha AM, Britt JK, De Jesus-Cortes H, Gonzales KL, Lee A, Moosmang S, Hofmann F, Pieper AA, et al. 2012. Forebrain elimination of Cacna1c mediates anxiety-like behavior in mice. Mol Psychiatry 17: 1054-1055.

Lee S, Kim SJ, Kwon OB, Lee JH, Kim JH. 2013. Inhibitory networks of the amygdala for emotional memory. Front Neural Circuits 7: 129.

Likhtik E, Popa D, Apergis-Schoute J, Fidacaro GA, Paré D. 2008. Amygdala intercalated neurons are required for expression of fear extinction. Nature 454: 642-645.

Maren S. 1996. Synaptic transmission and plasticity in the amygdala. An emerging physiology of fear conditioning circuits. Mol Neurobiol 13: $1-22$.

Maren S. 1999. Neurotoxic basolateral amygdala lesions impair learning and memory but not the performance of conditional fear in rats. J Neurosci 19: 8696-8703.

Maren S. 2000. Auditory fear conditioning increases CS-elicited spike firing in lateral amygdala neurons even after extensive overtraining. Eur $J$ Neurosci 12: 4047-4054.

Maren S. 2001. Neurobiology of Pavlovian fear conditioning. Annu Rev Neurosci 24: 897-931.

Maren S, Fanselow MS. 1996. The amygdala and fear conditioning: has the nut been cracked? Neuron 16: 237-240.

Maren S, Quirk GJ. 2004. Neuronal signalling of fear memory. Nat Rev Neurosci 5: 844-852.

Matsumoto Y, Kataoka Y, Watanabe Y, Miyazaki A, Taniyama K. 1994. Antianxiety actions of $\mathrm{Ca}^{2+}$ channel antagonists with Vogel-type conflict test in rats. Eur J Pharmacol 264: 107-110.
McKinney BC, Murphy GG. 2006. The L-type voltage-gated calcium channel $\mathrm{Ca}_{\mathrm{V}} 1.3$ mediates consolidation, but not extinction, of contextually-conditioned fear in mice. Learn Mem 13: 584-589.

McKinney BC, Chow CY, Meisler MH, Murphy GG. 2008a. Exaggerated emotional behavior in mice heterozygous null for the sodium channel Scn8a (Nav1.6). Genes Brain Behav 7: 629-638.

McKinney BC, Schneider JS, Schafer GL, Lowing JL, Mohan S, Zhao MX, Heng MY, Albin RL, Seasholtz AF, Akil H, et al. 2008b. Decreased locomotor activity in mice expressing tTA under control of the CaMKII $\alpha$ promoter. Genes Brain Behav 7: 203-213.

McKinney BC, Sze W, White JA, Murphy GG. 2008c. L-type voltage-gated calcium channels in conditioned fear: a genetic and pharmacological analysis. Learn Mem 15: 326-334.

Myers KM, Davis M. 2002. Behavioral and neural analysis of extinction. Neuron 36: $567-584$

Pape HC, Pare D. 2010. Plastic synaptic networks of the amygdala for the acquisition, expression, and extinction of conditioned fear. Physiol Rev 90: $419-463$.

Pare D, Royer S, Smith Y, Lang EJ. 2003. Contextual inhibitory gating of impulse traffic in the intra-amygdaloid network. Ann N Y Acad Sci 985: 78-91.

Royer S, Martina M, Paré D. 1999. An inhibitory interface gates impulse traffic between the input and output stations of the amygdala. J Neurosci 19: $10575-10583$

Sah P, Westbrook RF, Lüthi A. 2008. Fear conditioning and long-term potentiation in the amygdala: what really is the connection? Ann N Y Acad Sci 1129: 88-95.

Shaban H, Humeau Y, Herry C, Cassasus G, Shigemoto R, Ciocchi S, Barbieri S, van der Putten H, Kaupmann K, Bettler B, et al. 2006. Generalization of amygdala LTP and conditioned fear in the absence of presynaptic inhibition. Nat Neurosci 9: 1028-1035.

Sinnegger-Brauns MJ, Huber IG, Koschak A, Wild C, Obermair GJ, Einzinger U, Hoda JC, Sartori SB, Striessnig J. 2009. Expression and 1,4-dihydropyridine-binding properties of brain L-type calcium channel isoforms. Mol Pharmacol 75: 407-414.

Temme SJ, Bell RZ, Pahumi R, Murphy GG. 2014. Comparison of inbred mouse substrains reveals segregation of maladaptive fear phenotypes. Front Behav Neurosci 8: 282.

Thompson AJ, Duke RK, Lummis SC. 2011. Binding sites for bilobalide, diltiazem, ginkgolide, and picrotoxinin at the 5-HT3 receptor. Mol Pharmacol 80: $183-190$.

Tovote P, Fadok JP, Luthi A. 2015. Neuronal circuits for fear and anxiety. Nat Rev Neurosci 16: 317-331.

Trouche S, Sasaki JM, Tu T, Reijmers LG. 2013. Fear extinction causes target-specific remodeling of perisomatic inhibitory synapses. Neuron 80: $1054-1065$

Weisskopf MG, Bauer EP, LeDoux JE. 1999. L-type voltage-gated calcium channels mediate NMDA-independent associative long-term potentiation at thalamic input synapses to the amygdala. J Neurosci 19: 10512-10519.

White JA, McKinney BC, John MC, Powers PA, Kamp TJ, Murphy GG. 2008. Conditional forebrain deletion of the L-type calcium channel $\mathrm{Ca}_{\mathrm{V}} 1.2$ disrupts remote spatial memories in mice. Learn Mem 15: 1-5.

Wiltgen BJ, Godsil BP, Peng Z, Saab F, June HL, Linn ML, Cook JM, Houser CR, O'Dell TJ, Homanics GE, et al. 2009. The $\alpha 1$ subunit of the GABA(A) receptor modulates fear learning and plasticity in the lateral amygdala. Front Behav Neurosci 3: 37.

Wolff SB, Gründemann J, Tovote P, Krabbe S, Jacobson GA, Müller C, Herry C, Ehrlich I, Friedrich RW, Letzkus JJ, et al. 2014. Amygdala interneuron subtypes control fear learning through disinhibition. Nature 509: 453-458.

Woodruff AR, Sah P. 2007. Networks of parvalbumin-positive interneurons in the basolateral amygdala. J Neurosci 27: 553-563.

$\mathrm{Xu}$ W, Lipscombe D. 2001. Neuronal Ca $1.3 \alpha_{1}$ L-type channels activate at relatively hyperpolarized membrane potentials and are incompletely inhibited by dihydropyridines. J Neurosci 21: $5944-5951$.

Zhu Y, Romero MI, Ghosh P, Ye Z, Charnay P, Rushing EJ, Marth JD, Parada LF. 2001. Ablation of NF1 function in neurons induces abnormal development of cerebral cortex and reactive gliosis in the brain. Genes Dev 15: 859-876.

Received April 13, 2017; accepted in revised form July 17, 2017. 


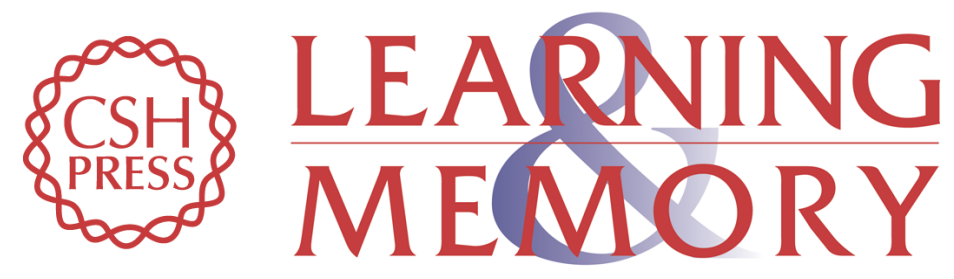

\section{The L-type voltage-gated calcium channel Cav1.2 mediates fear extinction and modulates synaptic tone in the lateral amygdala}

Stephanie J. Temme and Geoffrey G. Murphy

Learn. Mem. 2017, 24:

Access the most recent version at doi:10.1101/Im.045773.117

\section{Supplemental http://learnmem.cshlp.org/content/suppl/2017/10/05/24.11.580.DC1 Material}

References This article cites 60 articles, 20 of which can be accessed free at: http://learnmem.cshlp.org/content/24/11/580.full.html\#ref-list-1

Creative This article is distributed exclusively by Cold Spring Harbor Laboratory Press for the Commons first 12 months after the full-issue publication date (see

License http://learnmem.cshlp.org/site/misc/terms.xhtml). After 12 months, it is available under a Creative Commons License (Attribution-NonCommercial 4.0 International), as described at http://creativecommons.org/licenses/by-nc/4.0/.

Email Alerting Receive free email alerts when new articles cite this article - sign up in the box at the Service top right corner of the article or click here. 